\title{
U.S. Exporters: A Rare Breed
}

\author{
Rubén Hernández-Murillo
}

$\mathrm{U}$ S. firms rarely engage in international trade. In 2000, for example, there were 5.5 million firms in the United States; of these only about 4 percent were exporters. And the top 10 percent of these exporters accounted for 96 percent of total U.S. exports.

Not surprisingly, goods-producing firms account for the majority of exports (as measured by value). The table shows the distribution of exporting firms among 10 manufacturing industries ranked by their share of total manufacturing employment in 2002. Most manufacturing industries have some firms that export, but the share of those firms in each industry is relatively small, varying between 12 and 38 percent for the larger industries and between 12 and 25 percent for the smaller industries. Furthermore, across all industries, on average, a firm's foreign shipments represent only a small proportion (never exceeding 21 percent) of total shipments. In manufacturing as a whole in 2002, only 18 percent of firms were exporters and only about 14 percent of total firm shipments were exports.

Not only are exporting firms rare, they also stand out in several ways: Studies show that exporting firms are more productive in terms of value-added per worker and total factor productivity and that they ship a higher volume of products. They use more skilled workers, capital, and sophisticated technology than nonexporting firms. They also pay higher wages and are more innovative. (These differences persist even after accounting for firm size and industry type.)

On the surface, exporting seems beneficial. So why don't more firms export? One important distinction may offer a clue: Although the productivity level of exporting firms is higher than that of non-exporting firms, their productivity growth is not-which suggests that high productivity is a requirement for and not a consequence of engaging in international trade. High entry costs for exporting may be a barrier to all but the most efficient firms. At the same time, economists have also found that once firms begin exporting they experience faster growth than non- exporting firms in both employment and output (in both foreign and domestic shipments). ${ }^{1}$

Andrew Bernard and J. Bradford Jensen, along with co-authors, argue that the higher initial productivity of exporters, combined with higher output and employment growth after entry, suggests an important role for trade liberalization (a reduction of trade barriers) in improving the aggregate productivity of the economy. ${ }^{2}$ The reason is that a reduction in trade barriers would improve the profits of existing exporting firms and would reduce the initial productivity level necessary for additional firms to enter the export market. This additional entry would, in turn, generate an increased demand for labor and therefore higher wages. Low-productivity non-exporting firms would be forced to exit the industry, and both capital and labor factors would be reallocated from the less efficient non-exporting firms to the more efficient exporting firms. This would increase average productivity in the industry. Because the reallocation of factors occurs both within and across industries, this would translate into productivity gains for the entire economy.

${ }^{1}$ Bernard, Andrew B. and Jensen, J. Bradford. "Exporting and Productivity in the USA.” Oxford Review of Economic Policy, 2004, 20(3), pp. 343-57.

${ }^{2}$ Bernard, Andrew B.; Jensen, J. Bradford; Redding, Stephen J. and Schott, Peter K. "Firms in International Trade." Journal of Economic Perspectives (forthcoming).

\begin{tabular}{|c|c|c|c|c|c|}
\hline $\begin{array}{c}\text { Industry } \\
\text { employment } \\
\text { share rank }\end{array}$ & NAICS & Industry & $\begin{array}{l}\% \text { of } \\
\text { firms }\end{array}$ & $\begin{array}{l}\% \text { of firms } \\
\text { that export }\end{array}$ & $\begin{array}{c}\text { Mean exports } \\
\text { as \% of total } \\
\text { shipments }\end{array}$ \\
\hline 1 & 336 & Transportation equipment & 3.4 & 28 & 13 \\
\hline 2 & 332 & Fabricated metal product & 19.9 & 14 & 12 \\
\hline 3 & 311 & Food manufacturing & 6.8 & 12 & 15 \\
\hline 4 & 334 & Computer/electric product & 4.5 & 38 & 21 \\
\hline 5 & 333 & Machinery manufacturing & 9.0 & 33 & 16 \\
\hline 17 & 313 & Textile mills & 1.0 & 25 & 13 \\
\hline 18 & 314 & Textile product mills & 1.9 & 12 & 12 \\
\hline 19 & 312 & Beverage/tobacco product & 0.7 & 23 & 7 \\
\hline 20 & 324 & Petroleum/coal product & 0.4 & 18 & 12 \\
\hline \multirow[t]{2}{*}{21} & 316 & Leather/allied product & 0.4 & 24 & 13 \\
\hline & & Aggregate manufacturing & 100.0 & 18 & 14 \\
\hline
\end{tabular}

